Higher education accreditation in the Philippines: A literature review

Ching, Gregory S. $\bowtie$

Lunghwa University of Science and Technology, Taiwan, ROC (gregory_ching@yahoo.com)

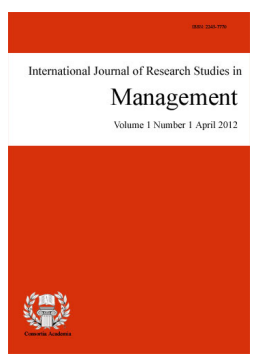

ISSN: $2243-7770$

Received: 18 April 2012

Available Online: 3 July 2012

Revised: 20 June 2012

DOI: $10.5861 /$ ijrsm.2012.162
Accepted: 1 July 2012

OPEN ACCESS

\title{
Abstract
}

This paper discusses the historical perspective, rationales, implications, different types and processes that undergoes in the accreditation of private higher educational institutions in the Philippines. As a result, higher education accreditation in the Philippines is centered on four key result areas, namely: quality of teaching and research, support for students, relations with the community, and management of resources.

Keywords: accreditation; higher education; Philippines; institutional performance; outcome-based evaluation 


\section{Higher education accreditation in the Philippines: A literature review}

\section{Introduction}

Pursuit of excellence is one of the main goals of almost all educational institution. At the same time the expansion, diversification, internationalization, privatization and globalization of higher education systems, has also generated worldwide growing concern for the quality of higher education processes. More so higher education institutions now are faced with challenges of accountability, value adding and transparency (Kingsbury, 2007a). Recently the competition in higher education rankings, together with the pressure brings forth by the society's demand for skilled human capital resources; higher education institutions are really having a hard time to outperform each other (Kingsbury, 2007b). In order to attain this goal, endless measures are being taken; upgrading both academic curriculum and physical facilities of the school, streamlining administrative tasks are just some of these measures. But how can a school claim that it has reached that certain level of excellence? One approach is to use accreditation systems (Hernes \& Martin, 2005).

\section{What is Accreditation?}

Adelman (1992) stated that accreditation refers to "a process of quality control and assurance whereby, as a result of inspection or assessment, an institution or its programs are recognized as meeting minimum acceptable standards". While, APA (2008) mentioned that Accreditation is both a status and a process. As a status, accreditation provides public notification that an institution or program meets standards of quality set forth by an accrediting agency. As a process, accreditation reflects the fact that in achieving recognition by the accrediting agency, the institution or program is committed to self-study and external review by one's peers in seeking not only to meet standards but to continuously seek ways in which to enhance the quality of education and training provided.

In the United States, the term "accreditation" is most often used with reference to schools and hospitals. Accreditation of these institutions is performed by private nonprofit membership associations known as accrediting agencies. These agencies which are consist of private educational associations of regional or national scope; develops evaluation criteria and conduct peer evaluations to assess whether or not those criteria are met. Institutions and/or programs that request an agency's evaluation and that meet an agency's criteria are then "accredited" by that agency (DOE, 2008).

While in the Philippines, accreditation is considered a concept based on self-regulation which focuses on evaluation and the continuing improvement of educational quality, a process by which institutions or programs continuously upgrade their educational quality and services through self-evaluation and the judgment of peers. A status granted to an educational institution or program which meets commonly accepted standards of quality or excellence (PAASCU, 2006b).

Accreditation is used as an indirect indicator of quality which may be used for differentiating programs and institutions in terms of quality (Tayag, 2005). At the same time, it is a means for promoting quality improvement (de Guzman, 2003). It is also a way of encouraging those schools adjudged to have attained desirable standards to do even better (Khoo, Majid, \& Chaudhry, 2003). Simply put, accreditation is a means of stimulating and accelerating the institutional growth and development of schools desiring to achieve excellence, relevance, and effectiveness. Ultimately, the goal of accreditation is to ensure that education provided by institutions of higher education meets acceptable levels of quality.

\section{Higher Education Policy in the Philippines}

In a speech by the Minister of National Education of Greece in a meeting of the OECD Education Ministers 
held in Athens in June 27, 2006, Sec. Marietta Giannakou stated that "Higher education plays a vital role in driving economic growth and social cohesion..... Every country is different, and there were many points of view. But we agree that a major program of reform is needed, giving more emphasis to outcomes in particular" (OECD, 2006).

More than a decade ago, Boyd and Plank (1994) had already stated that there is a growth in the recognition of higher education as a strategic factor in national economic welfare. Delaney (2002) also added that in the United States educational policy is being touted as a major concern especially in light of the various changes in educational governance both at the local schools and school district levels. For this reasons, educational policy has become a high priority issue.

\subsection{Policy}

Policy has many definitions, as four decades ago Cunningham (1963) said that policy is like an elephant you can recognize one when you see it, but it is somewhat hard to define. While, Micua (2000) stated that policy is a statement that guides to the actions or decisions of people in an organization. It is intended to be a binding guide on the actions of those designated by the statement. It is formulated and adopted through a political process, which acknowledges the reality and legitimacy of conflicting interests and desires among its participants.

Cadwell and Spinks (1988) define policy as a statement of purpose and one or more broad guidelines as to how that purpose is to be achieved, which, taken together, provides a framework for the operation of the school. They further state that policy may allow discretion in its implementation, with the basis for that discretion often stated as part of policy. While, Sergiovanni, Burlingame, Coombs, and Thurston (1999) refer to policy as any authoritative communication about how individuals in certain positions should behave under specified conditions.

Although there are indeed various definitions of policy, there are a number of common elements inherent in their definitions:

$>$ Policy is a formalized act;

$>\quad$ Policy has a pre-agreed objectives;

$>\quad$ Policy is approved or sanctioned by an institutional body or authority; and

$>\quad$ Policy provides some kind of standard for measuring performance.

\subsection{Educational Policy}

Micua (2000) stated that educational policy is a statement which serves as a binding guide, enforceable and enforced by the educational constituency responsible for its formulation. It is adopted through collegial agreement which acknowledges the conflicting interests and desires of all those who will be affected by it. While, Zajda (2005) also mentioned that educational policy are statements that often refer to primary, secondary, vocational, and higher education indicators and other aspects of education. Sergiovanni et al. (2004) also mentioned that importantly educational policies are influenced by demands for excellence and efficiency, with state governments assuming direct and highly regulatory responsibility for change.

OECD (2002) even published eight key strategies in towards educational policies that aim to help in promoting educational services for the people:

$>\quad$ A systematic approach to policy developments and integration;

> A strong and equal partnership with the education systems; 
$>$ A universal approach to access, with particular attention to children in need of special support;

Substantial public investment in services and infrastructure;

$>$ A participatory approach to quality improvement and assurance;

Appropriate training and working conditions for staff in all forms of provisions;

$>$ Attention to evaluation, monitoring and data collection; and

$>$ A framework and long-term agenda for research and evaluation.

OECD (2006) announced the six major areas in higher education that need immediate reforms:

$>$ Funding;

$>\quad$ More equitable education;

$>$ A clearer focus on what students learn;

$>$ Promote responsiveness and diversity;

$>\quad$ Research and innovation; and

$>$ Migration and internationalization.

Here we could see that higher education cannot escape major change. Sometimes change can be difficult, but with the necessary effort and policies. Change could be given a chance to succeed.

\subsection{Policy making}

Micua (2000) stated that policy making is the process that is undertaken to arrive at a collegial agreement. A collegial agreement is the sharing of authority; consensual agreement, common decision, collegial decision "without any contradiction in meaning", while a consensual agreement is not very easy to achieve. But it can be achieved for as long as there is no haste and no panic. For as long as there is trust. This will guarantee that the policy will be adhered to because those who are affected by it have been involved in the formulation, because such a formation has been brought about in the spirit of collegiality.

Developing educational policy with the concomitant processes is an exercise fraught with a multitude of values and principles (Delaney, 2002). Taylor, Rizvi, Lingard, and Henry (1997), mentioned that power and control are two primary values in the policy-making process. While, Pal (1987) suggested that there are three types of values worth considering when dealing with policy making:

> Content values - should decisions be made by a core group or should the decision - making process be open to a much wider involvement on the part of stakeholders.

$>$ Process values - these are the values as representing how to do something or, more specifically, how policies should be implemented and delivered. These are key questions that educators grapple with on a daily basis and which consume a considerable amount of valuable time, a commodity which is always in great demand in education.

$>$ Target group values - this is to whom the policy is for. The policy process by its very nature is full of competing interests and the various groups involved in those competing interests will obviously put forth claims that it is their specific group that is more deserving. Pal suggested the existence of two types of groups - those that are positively valued such as the elderly, the very young, the handicapped, women, racial, and minorities. While, the other is the negatively valued such as large businesses, large 
unions, and professionals.

Wirt and Kirst (1992) suggested four values that they consider to be subsumed in school policy:

$>$ Quality - this value is seen as instrumental, a means to another value goal, namely the fulfillment of diverse human purposes, thereby making life worth living and individuals worthwhile.

$>$ Efficiency - this value takes two forms. Economic were in it is to minimize the costs while maximizing gains. Accountability were in it is to oversight and the control of the local exercise of power.

$>$ Equity - this is the use of political authority to redistribute critical resources for the satisfaction of human needs.

$>$ Choice - this value refers to local school authorities having the opportunity to make policy decisions or to reject them.

To further understand the process of policy making, it is also important to know some basic principles in educational policy making. The distinction between values and principles is sometimes blurred in various educational issues but nonetheless, it is imperative that educators understand the differences when examining educational policy. According to Micua (2000), principles are defined as general truths or laws, basic to other truths. In educational policy, values are exactly as the name suggests. These are standards or precepts which the policy-maker considers as important as to have them permeate the specific policy. Principles are general truths which are kept in mind when developing various policies.

Olssen, Codd, and O'Neill (2004) mentioned that educational policy as policy was taken for granted and policy-making was seen more as a democratic consensual process than a political one. Today educational policies are the focus of considerable controversy and overt public contestations. Educational policy making has become highly politicized. As we moved into the twenty-first century, standards and assessments dominate the school improvement conversation. Whatever the values being contested they are influenced by the press for standards. The future of schooling will be determined by how standards and related issues are shaped and resolved. Throughout this process, school administrators will need to maintain the confidence of their many constituents and publics. The flow of images they communicate to their constituents will determine whether such confidence is maintained, hence, the need for effective educational policies making.

\section{Accreditation in the Philippines}

Hernes (2005) mentioned that the accreditation mechanism in the Philippines was developed between the 1950s and 1970s. In about 1951, after the Philippine's independence from the United States, a group of educators from the private higher education institutions decided to establish a system of common standards for Catholic institutions. Later, four accreditation agency were created successively for each segment of the higher education systems (Sectarian Schools, Universities \& Colleges, Technical \& Vocational Schools, Government/Public Institutions), each of which developed its own accreditation standards and structures and was made responsible for the accreditation of institutions within its specific segment.

According to the Philippine Constitution (DepEd, 2008), Executive Order No. 202 in December 24, 1969 created the Presidential Commission to Survey Philippine Education (PCSPE). In 1970, PCSPE started to submit policy recommendations to both improve and strengthen the higher education in the Philippines. Among others, it recommended that schools should be encouraged to join or organize accrediting associations, and that a Federation of Accrediting Agencies of the Philippines be established. This recommendation was referred to as the "Integrated Reorganization Plan (IRP)".

Later on in accordance to the previous proposal, Presidential Decree No. 1 approved and adopted the IRP 
(Pearson, 2007a). Followed by Presidential Decree No. 6-A; "Educational Development Decree of 1972" (LawPhil, 2000) and Presidential Decree No. 1200; "NEDA Five-Year Plan of 1977" (Pearson, 2007b) both having the provisions that accreditation programs shall be one of the strategies to achieve education and human capital development goals. Consequently, these policies played a very crucial and important role in the legal basis of accreditation in the Philippines.

In 1977, a non-stock, non-profit, non-governmental, umbrella organization called the Federation of Accrediting Agency in the Philippines (FAAP) was created to serve as the coordinating body with the government, which has the sole aim of upgrading the quality of Philippine education through voluntary accreditation. According to FAAP (2005), they are currently composed of three national accrediting associations for private educational institutions namely: the Association of Christian Schools and Colleges Accrediting Agency, Inc. (ACSC-AAI); the Philippine Accrediting Association of Schools, Colleges and Universities (PAASCU); and the Philippine Association of Colleges and Universities Commission on Accreditation (PACUCOA).

For government owned institutions, the National Network of Quality Accrediting Agency (NNQAA) was organized and tasked as the one responsible for coordinating accrediting agencies which accredits government owned institutions (AACCUP, 2003a; PAPSCU, 2006). NNQAA is composed of two agencies namely: the Accrediting Agency of Chartered Colleges and Universities of the Philippines (AACCUP) and the Association of Local Colleges and Universities Commission on Accreditation (ALCUCOA).

In general, educational institutions in the Philippines should go through one form of accreditation which is to be "recognized by the government". In addition to government recognition, private, voluntary accreditation by a recognized accrediting agency provides the opportunity for an educational institution to attain standards above those prescribed as minimum requirements by the government (PAASCU, 2006b).

\subsection{Basic principle of accreditation in the Philippines}

Primary accreditation is based upon accepted standards (Hernes \& Martin, 2005). Each educational institution seeking accreditation will be evaluated in terms of the appropriateness and adequacy of its philosophy, mission vision, and objectives and the degree and competence with which it achieves its goals. An accredited institution should effectively organize its human, financial and physical resources in order to accomplish its institutional philosophy and objectives (FAAP, 2005).

Accreditation is less of a competitive effort among member institutions than a realistic appraisal of each school's resources and its efficient utilization to help the institution achieve its goals (FAAP, 2005). Similarly, it provides institutional growth through continuing self-evaluation and peer visitation. Any educational institution is eligible to apply for the accreditation of any of its programs provided the application is presented to the Board of Directors of the accrediting agency to which it is applying.

Schools seeking accreditation shall undergo the different stages of the accreditation process. Terms and conditions of each stage shall be complied with before any school moves into the succeeding stage. Membership to the accrediting agency shall be granted only to those schools that have gone through all the stages of the accreditation process. After being accredited, each institution is expected to carry on a continuous program of school improvement. A member school may be advised, warned, placed on probation, or dropped from membership for failure to conform satisfactorily to the standards set by the accrediting agency or for failure to show a reasonable amount of progress since the last report.

\subsection{Different levels of accreditation in the Philippines}

According to Commission on Higher Education (CHED, 2007) Memorandum Order No. 1 Series of 2005 revised "Policies and Guidelines on Voluntary Accreditation in Aid of Quality and Excellence in Higher 
Higher education accreditation in the Philippines: A literature review

Education", benefits and incentives are granted according to the level of accreditation. Educational programs are initially classified as candidate and then gradually incurred one of four accredited levels. Accordingly different requirements and levels of difficulty come along with the various levels of accreditation (CHED, 2007; FAAP, 2005; PAASCU, 2006b).

Candidate Status are granted for programs which have undergone a preliminary survey visit and are certified by the federation/network as being capable of acquiring accredited status within two years.

Level I - Accredited Status are granted for programs which have been given initial accreditation after a formal survey by the accrediting agency and duly certified by the accreditation federation /network, effective for a period of three years.

Level II - Re-accredited Status are granted for programs which have been re-accredited by the accrediting agency and duly certified by the accreditation federation/network, effective for a period of three or five years based on the appraisal of the accrediting agency. This also means that an institution could maintain its Level I status or increase to Level II depending upon its performance and improvements during the previous level.

Upon reaching an accreditation Level I/Level II educational institutions would not only enjoy limited visitation, inspection and/or supervision by CHED supervisory personnel or representatives, but will also have full administrative deregulation, provided that reports of promotion of students and lists of graduates are available for review by CHED at all times.

More importantly, financial deregulation in terms of setting of tuition and other school fees and charges are granted. At the same time, the institution has the authority to revise its curriculum and give degrees from accredited courses or programs as long as it complies with the minimum requirements set by CHED. Priority in the awards of grants/subsidies or funding assistance from CHED-Higher Education Development Fund (HEDF) for scholarships and faculty development, facilities improvement and other development programs. Finally, the right to use on its publications or advertisements the word "ACCREDITED," pursuant to CHED policies and rules (CHED, 2007).

Level III - Re-accredited Status for programs which have been re-accredited and have met the additional criteria/guidelines set by the federation/network for this level. In this level, undergraduate programs must be able to justify its having a reasonably high standard of instruction together with a highly visible community extension program. A description of the programs, the nature and extent of student, faculty and staff involvement, and other details shall be required documentation for this indicator.

In addition, a highly visible research tradition should be followed and must be observable over a reasonable period of time with emphasis on the following criterion: provision for a reasonable budget, quality of completed outputs, measurable result such as publication, and the like, involvement of a significant number of faculty members, and finally a visible, tangible and measurable impact on the community.

A strong faculty development tradition evidenced by an appropriate budget allocation and/or systematic plan for faculty development programs is also needed. Having existence of working consortia or linkages with other schools and/or agencies is encouraged. Documentary evidence shall include a description of the nature, mechanism, working agreements and other details of consortia. None the less, an extensive and functional library and other learning resource facilities should be maintained in order to facilitate research and technology relates tasks (CHED, 2007; FAAP, 2005; PAASCU, 2006b). It is evident that the additional focus on research and community involvement of educational institutions is to encourage a more holistic and well developed institution of learning.

As for the benefits of Level III, educational institution shall have the authority to offer new courses allied to existing Level III courses without need for prior approval, provided that the concerned CHED Regional Office (CHEDRO) is duly informed. In addition, privilege to apply for authority to offer new graduate programs, open 
Ching, G. S.

learning/distance education, extension classes and to participate in the transnational education (CHED, 2007).

Level IV - Accredited Status is given to accredited program which are highly respected and should have the quality, prestige and authority comparable to similar programs in excellent foreign universities. In addition, educational institution should have full documentation and evidence on research as seen in the number, scope and impact of scholarly publications in refereed national and international journals. Similarly in teaching and learning as proven in excellent performance of graduates and continuing assessment of student achievement. Evidence on community service and impact of contributions to the economic and social upliftment on both regional and national levels should be provided. More evidence of international linkages and consortia, together with a well-developed planning process which support quality assurance mechanisms must exist (PAASCU, 2006b). Besides the benefits and privileges of the previous levels, Level IV educational institutions shall be granted full autonomy for all programs for the duration of its Level IV accredited status.

\subsection{The accreditation process}

In general, an academic institution would initially file an application together with the required documents to the accrediting agency it wants to apply. Upon acceptance of the institution's application a schedule is given to which when the agency would conduct the preliminary survey. Normal duration of this period is from one to two years. Acceptance of the application is not accreditation and does not assure eventual accreditation. It is an indication that an institution is progressing toward accreditation. Only after passing the preliminary survey shall the institution begin its actual accreditation process (AACCUP, 2003b; FAAP, 2005; PAASCU, 2006a).

Upon start of the accreditation process, the institution shall conduct self survey using survey forms given by the accrediting agency. Institutional self survey allows an institution to documents its strengths and weaknesses in relation to its mission, goals, objectives, faculty and human resources, financial capabilities, and other higher structural factors of a higher educational institution (Hernes \& Martin, 2005). The statements in the survey forms are more qualitative rather than quantitative. A consultant may assist in the preparation of the survey. A number of areas are covered some samples are as such: Administration, Community Involvement, Faculty, Instruction, Laboratories, Instructional Media (Library), Physical Plant, and Student Services (AACCUP, 2003b; APACC, 2004; FAAP, 2005; PAASCU, 2006a). Furthermore, the criteria and survey instruments are merely tools to help the school measure educational quality. They are intended to serve as a guide for educational institutions as they strive for excellence and for accreditors as they assess institutional achievement.

After the self survey report is made, institution shall then solve the problems identified by the report and the report will then be presented to the board of trustees of the accrediting association. A schedule for the formal accreditation will be given, only after passing the formal accreditation process, shall the school be granted its corresponding accredited levels together with the number of years. Re-accreditation is then done according to the number of years granted on the previous accreditation, thus an educational institution might lose or improve its status of accreditation depending on its prior performance. Hence, the accreditation venture is not a onetime journey, but instead an endless cycle in pursuit of greater academic excellence.

\section{Recent figures}

As of June 2005, Philippines have around 1,500 higher education institutions offering a variety of education programs. With an estimated total number of students around 2.4 million of which 810,000 are accounted to the public higher education institutions (CHED, 2005; PAPSCU, 2006). There are around 12,000 higher education programs being offered in the Philippines with a total of only 1,550 accredited programs. Of these, 321 programs have level I accreditation, 1,049 with level II accreditation and 180 with level III accreditation. Only two institutions have attained level IV accreditation (CHED, 2002; PAPSCU, 2006). Even though that the number of accredited programs has increased from 282 in 1991 to 1,550 in 2005. Despite this dramatic increase in the number of accredited programs, the percentage $(12.92 \%)$ of accredited programs out of the total existing higher 
education programs is still very low (PAPSCU, 2006).

\section{Conclusion}

In a global point of view, marketization of higher education is inevitable with programs being measured through outcomes, and global qualifications recognized for purposes of employment, professional status, or even further academic study (PAPSCU, 2006). Benchmarking learning outcomes against world-class standards is very important. Thus, most countries employ both internal and external evaluation/accreditation systems to demonstrate institutional performance (Hernes \& Martin, 2005). Employing evaluation systems will thus ensure that educational systems match world-class standards.

The Philippines although having an accreditation system since early 1950, still haven't shown sign of improving education. Education is still declining (Miralao, 2004). In addition Gulosino (2002) also points out a number of facts in the current educational setting in the Philippines such as: tuition and school fees charged in private schools are much higher and, therefore, not pro-poor. The expansion of private schools will undermine the social nature of education and instead promote education as a costly and profit making enterprise. A solution for this issue might be the creation of a more formal mechanism to allow educational institutions to use economies of scale and mutual support for quality improvement, thus also lowering the cost of education and make it more accessible to the people.

The establishment of common standards for accreditation in each discipline could provide the mechanisms for the continuous improvement of educational institutions (Marilao, 2004). The outcome-based evaluations of the accreditation process are mostly focused on these key references, such as: the self-imposed standards of quality in terms of the institution's mission vision and objectives, the national educational benchmark set by government (CHED), professional and accrediting body requirements (ISO and/or FAAP), employment and industry expectations (market forces), and some international educational benchmarks such as the Washington Accord. Besides the prestige given to a member schools, accreditation is justified by the possession of quality standards and the unremitting effort to maintain them at a high level.

As evident from the requirements of the various accreditation levels, higher education institution accreditation in the Philippines is centered on four key result areas, namely: quality of teaching and research, support for students, relations with the community, and management of resources. Thus, by far accreditation in fact is a process that could bring out the best in all areas of the academic institution.

\section{References:}

AACCUP. (2003a). The agency for accreditation. Retrieved January 5, 2008, from http://www.aaccupqa.org.ph/ AACCUP. (2003b). The conduct of accreditation. Retrieved January 23, 2008, from http://www.aaccupqa.org.ph/ConductOfAccred.html

Adelman, C. (1992). Accreditation. In B. R. Clark \& G. R. Neave (Eds.), The encyclopedia of higher education. New York: Pergamon Press.

APA. (2008). What is accreditation? Retrieved January 20, 2008, from http://www.apa.org/ed/accreditation/faq1.html

APACC. (2004). Fundamentals of accreditation and certification. Retrieved January 20, 2008, from http://www.apacc4hrd.org/conf_workshop/apacc04/TP/04/

Boyd, W. L., \& Plank, D. N. (1994). The international encyclopedia of education. Pergamon.

Cadwell, B. J. \& Spinks, J. M. (1988). The self-managing school. Philadelphia, PA: Falmer.

CHED. (2002). Statistics: Accreditation of higher education programs. Retrieved December 24, 2007, from http://www.ched.gov.ph/statistics/accreditation.of.higher.education.programs.html

CHED. (2005). Statistics. Retrieved January 2, 2008, from http://www.ched.gov.ph/statistics/index.html

CHED. (2007). Policies and guidelines on voluntary accreditation in aid of quality and excellence in higher 
education. Retrieved January 20, 2008, from http://www.ched.gov.ph/policies/Digitized\%20CMOs/CMO\%202005/CMO_01_S_2005.pdf

Cunningham, G. (1963). Policy and practice. Public administration, 41, 229-238. <http://dx.doi.org/10.1111/j.1467-9299.1963.tb01786.x>

de Guzman, A. B. (2003). The dynamics of educational reforms in the Philippine basic and higher education sectors. Asia Pacific Education Review, 4(1), 39-50. <http://dx.doi.org/10.1007/BF03025551>

Delaney, J. G. (2002). Educational policy studies - A practical approach. Canada.

DepEd. (2008). Organizations. Retrieved January 20, 2008, from http://www.deped.gov.ph/about_deped/organizationlinks.asp?id=17

DOE. (2008). Accreditation in the United States. Retrieved January 20, 2008, from http://www.ed.gov/admins/finaid/accred/accreditation.html\#Overview

FAAP. (2005). FAAP primer. Quezon City: FAAP.

Gulosino, C., \& Tooley, J. (2002). The private sector serving the educational needs of the poor: A case study from the Philippines. Retrieved January 12, 2008, from http://www.ncl.ac.uk/egwest/pdfs/School.pdf

Hernes, G., \& Martin, M. (2005). Policy rationales and organizational and methodological options in accreditation: Findings from an IIEP research project. Paper presented at the Accreditation and the Global Higher Education Market.

Khoo, C., Majid, S., \& Chaudhry, A. S. (2003). Developing an accreditation system for LIS professional education programmes in Southeast Asia: Issues and perspectives. Malaysian Journal of Library \& Information Science, 8(2), 131-149.

Kingsbury, A. (2007a). The measure of learning. Retrieved January 10, 2008, from http://www.usnews.com/usnews/news/articles/070304/12college.htm

Kingsbury, A. (2007b). Special report - America's best graduate school. U.S. News \& World Report.

LawPhil. (2000). Presidential decrees No. 6-A September 29, 1972. Retrieved January 20, 2008, from http://www.lawphil.net/statutes/presdecs/pd1972/pd_6_a_1972.html

Micua, T. (2000). Educational policy in the Philippines. Philippines: Chiang Kai Shek College.

Miralao, V. A. (2004). The impact of social research on education policy and reform in the Philippines. International Social Science Journal, 56(179), 75-87. $<$ http://dx.doi.org/10.1111/j.0020-8701.2004.00476.x >

OECD (2002). Education policy analysis.

OECD (2006). Education policy analysis - Focus on higher education.

Olssen, M., Codd, J., \& O’Neill, A. (2004). Education policy: Globalization, citizenship and democracy. London.

PAASCU. (2006a). Accreditation process. Retrieved January 23, 2008, from http://www.paascu.org.ph/paascu-ACCREDITATION\%20PROCESS.html

PAASCU. (2006b). Frequently asked questions. Retrieved January 5, 2008, from http://www.paascu.org.ph/paascu-about\%20us-FAQ.html\#WHAT\%20IS\%20ACCREDITATION

Pal, L. A. (1987). Public policy analysis: An introduction. Toronto: Methuen.

PAPSCU. (2006). Accreditation: Charting the future of Philippine higher education. Retrieved January 23, 2008, from http://www.papscu.org.ph/community/index.php?option=com_content\&task=view\&id=34\&Itemid=1

Pearson, C. (2007a). Presidential Decree 1. Retrieved January 20, 2008, from http://laws.berneguerrero.com/presidential-decree-1/\#more-76

Pearson, C. (2007b). Presidential Decree 1200. Retrieved January 20, 2008, from http://laws.berneguerrero.com/presidential-decree-1200/\#more-1085

Sergiovanni, T. J., Burlingame, M., Coombs, F. S. \& Thurston, P. W. (1999). Educational governance and administration (4 ${ }^{\text {th }}$ Ed.). Needham Heights, MA: Allyn \& Bacon.

Sergiovanni, T. J., Kelleher, P., McCarthy, M. M. \& Wirt, F. M. (2004). Educational governance and administration (5 ${ }^{\text {th }}$ Ed.). Pearson.

Tayag, J. (2005). Importing the training provision for new types of skills needed in an emerging country: 
Higher education accreditation in the Philippines: A literature review

Philippines. Paper presented at the Accreditation and the Global Higher Education Market

Taylor, S., Rizvi, F., Lingard, B., \& Henry, M. (1997). Educational policy and the politics of change. London: Routledge.

Wirt, F. M., \& Kirst, M. W. (1992). Schools in conflict. Berkeley, CA: McCutchan.

Zajda, J. (2005). International handbook on globalization, education and policy research. The Netherlands. <http://dx.doi.org/10.1007/1-4020-2960-8> 
Ching, G. S. 